\title{
Dialectiek in de academische pathologie: RIP?
}

Citation for published version (APA):

de Bruine, A. P. (2006). Dialectiek in de academische pathologie: RIP? Maastricht University. https://doi.org/10.26481/spe.20060623ab

Document status and date:

Published: 23/06/2006

DOI:

10.26481/spe.20060623ab

Document Version:

Publisher's PDF, also known as Version of record

\section{Please check the document version of this publication:}

- A submitted manuscript is the version of the article upon submission and before peer-review. There can be important differences between the submitted version and the official published version of record.

People interested in the research are advised to contact the author for the final version of the publication, or visit the DOI to the publisher's website.

- The final author version and the galley proof are versions of the publication after peer review.

- The final published version features the final layout of the paper including the volume, issue and page numbers.

Link to publication

\footnotetext{
General rights rights.

- You may freely distribute the URL identifying the publication in the public portal. please follow below link for the End User Agreement:

www.umlib.nl/taverne-license

Take down policy

If you believe that this document breaches copyright please contact us at:

repository@maastrichtuniversity.nl

providing details and we will investigate your claim.
}

Copyright and moral rights for the publications made accessible in the public portal are retained by the authors and/or other copyright owners and it is a condition of accessing publications that users recognise and abide by the legal requirements associated with these

- Users may download and print one copy of any publication from the public portal for the purpose of private study or research.

- You may not further distribute the material or use it for any profit-making activity or commercial gain

If the publication is distributed under the terms of Article $25 \mathrm{fa}$ of the Dutch Copyright Act, indicated by the "Taverne" license above, 


\section{Dialectiek in de academische pathologie: RIP?}




\section{Colaton}

Basisontwerp en realisatie: Océ Business Services, Universteit Maastricht.

Hustratie omslag: "De Gebtoorte wam Venus", Sardro Botticell (1446-1510), detail.

15BN $90.568 \%-2.42 \cdot 4$

NUR 870

Alle rechten woorbehouden. Niets uit deze uitgove mag worden verveevowdigd opgeslagen in een geautomatiseend gegevensbestand of openbaar gemaknt, zonder voorafgaande schriftelike toestemming wande duteur of uitgever. 


\section{Dialectiek in de academische pathologie: RIP?}

\section{Rede}

uitgesproken bij de aanvaarding van het ambt van bijzonder hoogleraar KIinische Pathologie aan de Faculteit der Geneeskunde van de Universiteit Maastricht

op vrijdag 23 juni 2006

door

Dr. Adriaan P. de Bruine

\footnotetext{
v
}

M. Universiteit Maastricht 
"Bijna alles wat $u$ doet is onbelangrijk, maar het is erg belangrijk dat u het doet"

Mahatma Gandhi

2 oktober $1869-30$ januari 1948 
Mijnheer de Rector Magnificus, Zeer Gewalardeerde Toehoorders.

\section{Inleliding: De Titel}

Twintig jaar geleden werd ik als jonge arts-assistent pathologie door mijn opleider Prof.dr. Bosman in de gelegenheid gesteld om bij het Nederlands Tijdschrift voor Geneeskunde de zogenaamde "Auteurscursus" te volgen, in de hoop dat ik wat artikelen zou gaan schrijven. De belangrijkste les die ik hierbij leerde, was dat een titel helder en begrijpelijk moet zijn en de inhoud van het stuk moet weerspiegelen. "De vlag moet de lading dekken". U ziet dat deze cursus in ieder geval geen duurzaam effect heeft gehad. I $\mathrm{k}$ zal dan ook eerst nader ingaan op de titel van deze oratie.

Het zal U niet verbazen dat het vandaag gaat over het medisch specialisme pathologie. Meer in het bijzonder de academische pathologie. Pathologie (afgeleid van $\pi$ $\alpha \theta$ os, Grieks voor lijden of ziekte) betekent letterlijk "ziekteleer", en houdt zich bezig met de oorzaken, ontstaanswijzen, verschijnselen en gevolgen van ziekten. Hierbij worden veranderingen in organen, weefsels en cellen, die ontstaan in het kader van ziekten, door visuele waarneming vastgesteld, zowell met het blote oog als met behulp van microscopische technieken. De patholoog houdt zich bezig met het stellen van diagnosen, het bepalen van de prognose van ziekten en het bestuderen van de relatie tussen waargenomen afwijkingen en de effectiviteit van behandeling van ziektem.

Het begrip"academisch" wordt hier gebruikt als "samenhangend met de universiteit", met de academische Trias van patiëntenzorg, wetenschappelijk onderzoek en opleiding. Daarmaast heeft "academisch" een meer historische en romantische klank. De oorsprong van het woord "academie" ligt immers ten tijde van de oude Grieken. Het woord stond voor een Atheens gymnasium, waar een sport accommodatie was gevestigd en het heiligdom van de Attische held Akademos. Plato begon hier in 387 voor Christus zijn school voor filosofie en geestesontwikkeling, die gedurende meerdere eeuwen bloeide. Het begrip "dialectiek" sluit nauw aan bij de school van Plato en zijn belangrijkste leerling Aristoteles. In hun beschouwingen was dialectiek een discussievorm, die door het gebruik wan tegenstellingen de warheid probeert te winden. Door latere filosofen, zoals Hegel, Marx en Fichte, zijn de begrippen die deze tegenstellingen uitdrukken, de these en antithese, geintroduceerd. De controverse tussen these en antithese dient te worden opgeheven 
door de synthese. Stelling. tegenstelling en samenstelling. Mijn betoog bestaat uit deze drie componenten van dialectiek.

En RIP dan? RIP is een afkorting die in de geneeskunde vaak gebruikt wordt, ook op aanvragen voor onderzoek die de patholoog ontvangt van de behandelend arts. RIP staat dan woor "Ruimte Innemend Proces", een andere term voor een gezwel. De meest voorkomende aandoeningen van deze tijd zijn kanker, suikerziekte, longemfyseem, een hoog cholesterolgehalte, HIW/AIDS, hoge bloeddruk, ischemische hartziekten, CVA, asthma, galsteenlijden, maagzweren, rug- en gewrichtsklachten, Alzheimer en andere vormen van dementie, depressiviteit en angst. Van deze top 15 zijn in de klinische pathologie verreweg de meeste onderzoeken gericht op de diagnostiek van kanker, ofwel de oncologische diagnostiek. Dit vormt het centrale thema van mijn leeropdracht.

Het gebruik van afkortingen in de geneeskunde woert soms heel ver en kan tot misverstanden leiden, omdlat een afkorting voor velerlei uitleg vatbaar kan zijn. Berman beschreef het aantal en type afkortingen waarmee de patholoog geconfronteerd kan worden. in het Engelstalige medische jargon kwam hij tot 12097 afkortingen ${ }^{2}$. Zoals U zult gaan zien, is "R\|P" eveneens een afkorting met meerdere betekenissen en vormit daarmee de Rode draad In deze Presentatie.

\section{These: Requilescat In Pace}

Allereerst zal ik mij in de dialectische uiteenzetting bezig houden met de formulering van de "these".

De betekenis wan de afkorting RIP, die wellicht bij $U$ het eerst op zal komen, en ongetwijfeld de meest macabere, luidt: Requiescat in Pace, in het Engels: Rest In Peace. Dit is zoals U weet een bekend opschrift van grafzerken. In de context van de oratietitel zou dit kunnen leiden tot de gedachte dat de academische pathologie op sterven na dood is. In feite is deze gedachte zo gek nog niet, zeker wanneer we vanuit de buitenwereld maar het vak kijken. Het imago van de pathologie als medisch vakgebied is namelijk bedroevend. RiP zou hier kunnen staan voor Rampzalig Imago van de Pathologie.

In mijn eigen beleving is dit tenminste wel het geval. In de 22 jaar dat ik thans meedraai, bevinden wij pathologen ons consequent onderaan de medische hitparade. Ik spreek uit ervaring als ik stel, dat wanneer een patholoog met een charmante dame in gesprek raakt, de bij haar behoedzaam opgebouwde belangstelling abrupt en volledig weg zal ebben, als blijkt dat haar gesprekspartner geen chirurg is maar patholoog (of erger nog: patholoog-anatoom). Deze bekentenis resulteert 
doorgaans in een overhaast afscheid, vergezeld van een zwakke grimas, en onder het prevelen van de woorden: "O ja, Dokter Zeldenrust!l"

Belangrijk is de associatie van het vak met de dood en het postw mortale onderzoek, ook wel sectie, obductie of autopsie genoemd. De keren dat de pathologie de krantenkoppen heeft gehaald zijn vrijwel zonder uitzondering verbonden met overledenen en het verrichten van snij werkzaamheden in de krochten van de ziekenhuizen, inclusief de hiermee samenhangende repulsieve anti-anekdotes. Denk hierbij aan de zogenaamde "handel" in hersenvliezen in 1989, de overdracht van de ziekte van Creutzfeldt-Jakob via groeihormoon uit bij obductie verkregen hypofyses, de affaire rond het achterhouden en onverwacht weer tevoorschijn komen van kinderorganen na secties in het Engelse Alder Hey 3 en Bristol en, recent nog, de aanklacht van nabestaanden tegen het Nederlands Forensisch instituut over het terugkrijgen van de verkeerde organen 4 .

Mocht $U$ twijfelen aan mijn objectiviteit, dan verwijs ik naar een serie artikelen in 2004 gepubliceerd in NRC Handelsblad, over "beroepen met een negatief imago". U raadt het al: de patholoog was hier van de partij, en werd in éen lange adem genoemd met beroepen als: ongediertebestrijder, varkenshouder, visverwerker, tweedehands autoverkoper, abortusarts, rioolontstopper, vulinisman, rattenvanger, paardenslager, deurwaarder, parkeerwachter en prostituee. De bijdrage over de patholoog was getiteld: "Geinteresseerd in lijken"5. In de wiskunde zou men dan zeggen: Quod Erat Demonstrandum. Nog recenter is de publicatie begin 2006 in Vrij Nederland, getiteld: "Vertalers van de dood" 6 . Beide publicaties bevatten overigens een wisselend expliciete weergave van de werkzaamheden van onze collega's de Forensische of Gerechtelijk Pathologen, zijn van wisselende journalistieke kwaliteit en leveren daarmee een wisselende bijdrage aan het diskwalificeren van pathologen als pur sang "lijkensnijders". Belangrijk is het hier op te merken dat er in Nederland een scheiding bestaat tussen Forensische en Klinische Pathologie. De Forensische Patholoog heeft als voornaamste taak om in opdracht van het Ministerie van Justitie postmortad onderzoek te verrichten in gevallen van niet-natuurlijke dood, met vermoeden op een misdrijf. De Klinisch Patholoog doet daarentegen postmortale onderzoeken bij individuen die overleden zijn aan ziekte of ouderdom, de natuurlijke dood. Ik wil niet ontkennen dat secties als kwaliteitscontrole en onderwijs instrument een wezenlijk onderdeel dienen te blijven vormen van goede patientenzorg, maar er is meer wat de Klinisch Patholoog doet. De afdeling Pathologie in Maastricht verricht jaarlijks iets meer dan 200 
secties. Daartegenover staan de ruim 35000 jaarlijkse anderzoeken op cel-en weefsel preparaten afkomstig van levende patienten. U begrijpt de lichte ifritatie over de woortdurende associatie van de patholoog met de dood, en het gebrek aan erkenning van het werk voor de levenden.

is dit nu belangrijk of is dit uitsluitend een uiting van de langlarige frustratie van de orator? Als we met zijn allen van mening zijn dat de Pathologie een essentieel onderdeel moet bliven vormen wan patiëntenzorg is het zeker van groot belang. Een negatief imago heeft als belangrijk risico dat men ertoe zal neigen het vak te negeren. Dit risico speelt gelukkig niet bij de meeste van onze cliënten, de behandelende collega's in de huisartspraktijk en in de kliniek, van wie wij voldoende signalen krijgen dat onze inzet gewaardeerd wordt. Dit risico bestaat echter wel degelijk bij patienten, bestuurders en politici. Een niet te verwarlozen risico is verder het probleem van de "Nachwuchs". Zijn aanstaande collega's nog wel bereid om voor ons vak te kiezen? In Groot Brittamnië is er gedurende de laatste 10 jaar een halvering geweest van het toch al niet hoge percentage instromers in de opleiding Pathologie, namelijk wan $4.5 \%$ naar $2.3 \%$ van de basisartsen?. Hierwoor zou een combinatie van factoren verantwoordel ljk kunnen zijin, zoals een laag beroepsprofiel van de patholoog, de misconceptie van de patholoog als sectie-assistent, de geringe honorering, de afkalving wan de academische pathologie, en het negatieve imago van de pathologie na het Alder Hey schandaal. Verder zou de herkenbaarheid wan Pathologie in de nieuwe multidisciplinaire, geintegreerde medische curricula ten opzichte van de traditionele medische opleiding afgenomen kunnen zijn. Opvallend was dat de prestigleuze universiteiten van Oxford en Cambridge zich bevonden onder de faculteiten met de grootste belangstelling van medische studenten voor pathologie, suggererend dat een hoog niveau van academisch opleiden van belang is bij een positieve beroepskeuze voor de pathologie. Verder bleek pathologie onder vrouwen populairder te zijn dan onder mannen, wellicht een reflectie van de aantrekkingskracht van gunstige arbeidstijden in de pathologie op het viouwelijk geslacht en de afkeer van de lage status en beloning van de patholoog bij de mannen.

Naast een onveranderlijk negatief imago van de pathologie als domein van het postmortale onderzoek, zijn er nog andere potentiële bedreigingem, zoals het gevoel onder sommige vakgenoten, dat onze toekomst als "saaie coupekijkers" weinig opwindend is, dat alle denkbare afwijkingen al beschreven en daarmee oud nieuws zijn, en dat we vervangen zullen worden door artificlële intelligentie. Verder zijn er 
geesten binnen en buiten de pathologie, die door de stormachtige ontwikkeling van "moleculaire imaging" in de beeldvormende diagnostiek, menen dat de diagnose door de patholoog owerbodig zou kunnen worden. Evenzo zou de moleculaire biologie het einde van de diagnostische pathologie voorspellen: alle ziekten krijgen immers een gedefinieerd moleculair profiel ${ }_{\text {dus }}$ wie is nog geinteresseerd in de mening van de ouderwetse over het microscoop gebogen patholoog?

Tenslotte vormen strakkere regelgeving, negatieve publiciteit en een bevooroordeelde publieke opinie een bedreiging woor wetenschappelijk onderzoek, waarbij nader gebruik gemaakt wordt van het rijkelijk voorradige restmateriaal van patiënten in de pathologie archieven.

Het is duidelijk dat een significant afnemende belangstelling voor de pathologie en de opleiding tot patholoog een bedreiging vormen voor het voortbestaan van het vakgebied. Om dit tegen te gaan moet er gewerkt worden aan profilering en een algemene verbetering van het imago, binnen de geneeskunde opleiding, binnen de universitair medische wereid en in bredere maatschappelijke kring. Verbeteren van de Reputatie In de Pathologie, Resulteert In Profilering. Ik zal hiertoe in het resterende deel van dit betoog een aanzet geven. Tot zover deze these.

\section{Antithese : Renaissance In de Pathollogie}

Als dialectische antithese stel ik, dat de pathologie niet op sterven na dood is, maar dat juist sprake is van een wedergeboorte een Renaissance In de Pathologie. Wij kennen de "Renaissance" als de periode in het Europa van de $15^{\mathrm{e}}$ en $16^{\mathrm{e}}$ eeuw, aamsluitend aan en in reactie op de Middeleeuwen, waarin er een opbloei van beeldende kunsten, letteren en wetenschappen plaats vond, georiënteerd op de klassieke oudheid, met een herontdekking van de menselijke eigenwaarde in het humanisme. Een parallel naar de hedendaagse pathologie zou dan moeten zijn dat er thans sprake is van een opbloei van het vakgebied, na een lange, weinig veranderlijke periode, en dat de mens weer "de mat van alle dingen" (vrij naar Protagoras) zou moeten worden.

De Deense fillasoof Kierkegaand zei: "Life must be lived forward, but can only be understood backwards". We zullen daarom eerst een blik op het werleden van de geneeskunde en in het bijzonder de pathologie werpen ${ }^{8}$.

De Westerse geneeskunde vindt zijn oorsprong vooral in het oude Griekenland, vanaf de $6^{\mathrm{e}}$ eeuw voor Christus, met als hoogtepunt de school van Hippocrates van Kos (460-377 w.Chr), Oorspronkelijk werden ziekten verklaard vanuit een "animistische"zienswijze, waarbij bovem- 
natuurlijke en goddefijke krachten de verklaring vormden van ziekten. Later ontstond de meer wetenschappelijke "naturalistische" benadering, gekenmerkt door de opvatting dat ziekten een natuurverschijnsel waren. Zlekten zouden veroorzaakt worden door een verstoring van de balans van de wier lichaamswloeistoffen: slijm, bloed, gele en zwarte gal. Dit werd de humorale leer genoemd, welke gedurende vele eeuwen stand zou houden. Voor de anatomie bestond nog weinig belangstelling. Alleen Galenus van Pergamum (131-201), de Grieks-Romeinse liffarts van keizer Marcus Aurelius, heeft veel bijgedragen aan anatomische kennis, weliswaar voornamelijk op basis van studies in dieren. Het duurde tot in de Renaissance voordat de anatomische kennis zich echt ging ontwikkelen. Frappant hierbij is, dat waar de Renaissance een weder geboorte van kunsten en wetenschappen vertegenwoordigt, het in feite de geboorte van het specialisme pathologie vormde, aangezien pas in die tijd een begin gemaakt werd met het systematisch verrichten van secties, de eerste manifestatie van het huidige vakgebied 9 . Tot dat moment bevond het verrichten van lijkopeningen zich in de taboesfeer, waarin het zich incidenteel thans wederom bevindt. Van deze periode stamt ook de obsolete benaming "pathologische anatomie". Beroemd werd vooral de Brusselaar Andreas Vesalius (1514-1564), ofwel Andries van Wezel, de grondlegger van de moderne anatomische kennis. Het werk van Antonio Benevieni (1443-1502), geboortig in Florence, een ontwikkelde humarist en arts, behandelt verslagen van een honderdtal secties, die werden verricht wegens onzekerheden over het klinische zlektebeloop, en ter bepaling van de doodsoorzaak. Niet anders dan in de huidige uitoefening van de klinische pathologie zou je zeggen. Hij wordt wel aangeduild als de vader wan alle pathologen. Overigens bestonden er toen in strikte zin nog geen pathologen, en werden postmortale onder zoeken (vooral op lijken van misdadigers) verricht door chirurgijnen en hun concurrenten, de medicinae doctores, artsen met een academische opleiding In dit jaar van Rembrandt is de naam van de chirurgijn Claes Pietersz., alias Nicolaes Tulp, docent bij de meest beroemde anatomische les, in dit opzicht vermeldenswaardig.

Het vak, dat zich eerst uitsluitend moest baseren op studies gedaan met het blote oog, ontwikkelde zich in de mavolgende eeuwen geleidelijk tot wat het thans is. Instrumenteel hierbij was letterlijk de ontwikkeling van de microscoop, aan de basis waarvan Antonie van Leeuwenhoek stónd. Aanvankelijk een wetenschappelijke methode, werd het steeds meer een standaard instrument voor de patholoog, en maakte het ook mogelijk dat Rudolf Virchow ${ }^{10}$, de vader van de celbiologie, in 1858 zijn 
boek over de "Cellular Pathologie" kon lanceren, met de theorie dat ziekten gebaseerd zijn op afwijkingen in cellen, en dat er morfologische verschillen bestaan tussen ontstekingsprocessen en kanker, een belangrijke vooruitgang in de pathologische anatomie. In deze tijd kwamen tevens allerlei chemische technieken om weefsels aan te kleuren tot ontwikkeling, zoals de ook nu nog meest toegepaste HE (hematoxyline eosine) kleuring, die het mogelijk maakten om weefsels veel beter te kunnen bekijken met een microscoop". In de loop van de twintigste eeuw werden hier nieuwere technieken aan toegevoegd, zoals elektronen microscopie en enzym histochemie. In de laatste twee decennia van de vorige eeuw kwamen hier tenslotte immuunhistochemische technieken en nog recenter moleculaire technieken bij.

Immuuninistochemie, voortwloeiend uit de kennis van de immunologie, die zich ontwikkeld heeft in de tweede helft van de $20^{e}$ eeuw, stelt ons in staat om met behulp van antilichamen specifieke structuren ofwel antigenen in weefsels en cellen zichtbaar te maken. Toegevoegd aan een gedetailleerde microscopische beoordeling, biedt deze techniek, die de moleculaire samenstelling van weefsels en cellen kan ophelderen, de patholoog een onmisbaar hulpmiddel om afwijkingen beter te kunnen diagnosticeren.

De moleculaire biologie heeft zich als wetenschap in de laatste decennia van vorige eeuw eveneens razendsnel ontwikkeld. Mijlpalen hierbij zijn geweest de opheldering van de structuur van DNA als dragermolecuul wan onze erfelijke eigenschappen door de latere Nobelprijswinnaars Watson en Crick in 1953 en het in kaart brengen van de volgorde van de 3 miljard basenparen in het Humane Genoom project rond het millennium. Deze kennis kon zich ontwikkelen door belangrijke technische verbeteringen, zoals de mogelijkheid om DNA te vermeerderen in een reageerbuis met de polymerase kettingreactie (PCR), de ontwikkeling van microchip-en microarray technologie en de evolutie van steeds snellere en krachigigere computers. Wetenschappelijk gezien is er een belangri.jke verschuiving opgetreden van hypothese toetsend onderzoek naar descriptiefrobservationeel onderzoek, vooral in het z.g. micro-array gebaseerde onderzoek. Dit is gericht op het winderi van verschillen tussen 2 gedefinieerde groepen (b.v. kanker patienten met of zonder uitzaaingenl, door het simultaan bestuderen van de expressie van tienduizenden gerien of eiwitten. Voordeel van deze benadering is dat, door de gelijktijdige bestudering van vele factoren, in korte tijd veel gegevens -en hopelijk ook kennis-gegeneerd kunnen worden, die in combinatie met de blauwdruk vam het menselijke genoom, in theorle sneller kunnen 
leiden tot nieuwe oplossingen voor biologische vragstukken, nieuwe vormen van therapie, nieuwe methoden om risicofactoren voor ziekten in te schatten dan wel om ziekten in een vroege fase op te sporen. Er zijn echter ook nadelen. Dit technisch relatief ingewikkelde onderzoek is nog niet overall uitvoerbaar, vereist een grondige kennis van klinische epidemiologie en statistiek, en goede bio-informatica ondersteuning. Dit alles kan leiden tot voorbarige conclusies, wanneer de weliswaar vaak opzienbarende data verkregen zijn door slordigheden in de gebruikte methoden, de data onvoldoende onderbouwd zijn, of niet door andere onderzoekers gereproduceerd kunnen worden. Een groot risico van dergelijke I.g. "high throughput" studies betreft "overfitting": doordat het aantal variabelen dat geanalyseerd wordt (de tienduizenden genen) vele malen groter is dan het aantal waarnemingen (slechts tientallen patiënten), kan er een statistisch significant resultaat uitrollen zonder enige biologische relevantie en zonder repraduceerbaarheid in de algehele populatie ${ }^{2}$.

De moleculaire biologie is stellig bezig het profiel van de geneeskunde te veranderen. Er bestaan nu al nieuwe therapievormen, gebaseerd op gedane moleculaire ontdekkingen. De kennis van erfelijke ziekten, de diagnostiek van infectieziekten en stofwisselingsstoornissen zijn sterk verbeterd. De toenemende moleculaire kennis wormt ook de basis voor verbeterde visualisatie methoden in vivo in de patiënt "de z.g. moleculaire imaging waarover $i k$ al in de These sprak.

ook de uitoefening van de pathologie is aan moleculaire veranderingen onderhevig. De classificatie van bepaalde tumoren (zoals weke delen sarcomen en maligne lymfomen) is op grond van kenmerkende chromosomale afwijkingen (translocatles) nauwkeuriger geworden. De pathologie maakt daarnaast dankbaar gebruik van DNA "vingerafdruk" technieken voor de identificatie van patient materialen, ter voorkoming van de potentieel desastreuze gevolgen van onderlinge werwisseling hiervan.

De patholoog dient zich bij dit alles actief en in een centrale rol (tussen moleculair bioloog, epidemioloog, statisticus en bio-informaticus) te positioneren, en niet als een bedreigde species, en wel om drie redenen. Ten eerste, omdat de academische patholoog, vanuit het basale wetenschappelijk onderzoek en onderwijs op zijn terrein, reeds beschikt over een ruime kennis van de moleculaire biologie. Ten tweede, omdat al het moleculaire onderzoek staat of valt met een gedegen morfologische kennis van het uitgangsmateriaal, de weefsels en cellen, en alleen de patholoog hier in thuis is. Ten derde, omdat een diagnose geleverd door 
de patholoog op een simpele HE coupe, dankzij de gedurende wele eeu. wen opgebouwde empirische en clinico-pathologische kennis, vooralsnog een onovertroffen methode blijt: zowel wat betreft de kwantiteit en de kwaliteit van de gegenereerde informatie, als de kosten effectiviteit van de verrichting 13. De perifeer werkzame collega, die zelf niet direct kan beschikken over een moleculair diagnostisch lab, dient zich niet af te laten schrikken en in leder geval wat kennis ontwikkeling betreft bij te blijven. Immers, nadat de "high-throughput" micro-array stormen zijn overgewaaid, en een handzame, consistente en reproduceerbare dataset is overgebleven, zal de diagelijkse diagnostische praktijk gebruik kunnen maken van op maat gemaakte, en voor ledereen toepasbare sets van genen of eiwitten, of gewoon weer terug keren tot de vertrouwde en overal toepasbare immuunhistochemie.

Een derde factor in het veranderende profiel van de geneeskunde is de explosie van informatie technologie. Voor de patholoog zi.jn hierbij een goed werkend eigen laboratorium informatie management systeem, en de toepassing van de mogelijkheden van het internet belangrijk. Deze spelen een steeds gewichtigere ral in de patiëntenzorg enerzijds en in het onderwijs en wetenschappelijk onderzoek anderzijds. Het internet is essentieel voor het verwerven en overdragen van de exponentieel groeiende medische kennis en woor het raadplegen van de enorme beschikbare moleculaire databestanden. Voorts kan het, zeker in een visueel ingesteld vak als pathologie uitstekend ingezet worden als systeem voor telepathologie in de intercollegiale consultatieve sfeer.

De immunohistochemie, de moleculaire diagnostiek en de informatie technologie hebben de dagelijkse uitoefening van de diagnostische en experimentele pathologie geweldig veranderd.

Op een tijdsas van vijf eeuwen pathologie geprojecteerd, zien we dat deze veranderingen zich vooral in de laatste 25 jaar hebben afgespeeld. In chronologisch opzicht kunnen we derhalve veilig poneren dat wilj ons thans in een periode van "Renaissance in de Pathologie" bevinden.

Alvorens te komen tot de Synthese, zal ik eerst enkele woorden wijden alan patientenzorg wetenschappelijk onderzoek, onderwijs en opleiding.

\section{Risicobeheersing In de Patiëntenzorg}

n januari jongstleden is in Nederland gestart met een nieuw zorgstelsel. Hierbij lijkt er vooral aandacht te bestaan voor de financieel economische kant, met woortdurend gesteggel rond de nieuwe $\mathrm{DBC}$ 
declaratle systematiek, introductie van een nieuw ziektekosten verzekeringsstelsel, aandacht voor een "vraaggestuurde" zorg en introductie van marktwerking als panacee woor een steeds meer wankelende zorg. Weinig aandacht is er voor de inhoud, en voor de inbreng van de professionalis in de zorg.

In de Verenigde Staten heeft de Committee on Quality of Health Care van het Institute of Medicine reeds in 20016 criteria benoemd, waraan goede zorg in de $2 \eta^{e}$ eeuw zou moeten woldoen, en waarnaar alle spelers in het veld gezamenlijk zouden dienen te streven, te weten: effectiviteit, efficiêntie, tijdigheid, patient gecentreerdheid, gelijkwaardigheid en veiligheid'. Laten we eens bezien wat de bijdrage van de klinisch patholoog is bij het vervullen van deze 6 criterila.

Op de eerste plaats de "effectiviteit". Een behandeling is effectief indien deze werkzaam is, op wetenschappelijke onderbouwing berust en goed gedoseerd wordt, zonder over- of onder behandeling. De patholoog draagt hier wezenlijk aan bij, door iedere onderzoeksaanvraag te beantwoorden met een juiste diagnose, verwoord in een heldere conclusie, waarin liefst ook nog informatie omtrent prognose en gevoelig. heid voor therapie besloten zijn. Het Academisch Ziekenhuis Maastricht is bezig om de pattëntenzorg onder te brengen in multidisciplinaire zorglijnen, gecentreerd rond patiënten met een bepaalde categorie aandoening, zo ook de Oncologie. De oncologische zorglijn is ondergebracht bij het nieuwe Universitair Kankercentrum Maastricht, en is weer onderverdeeld in een $12-t$ tal verschillende tumorgebieden, op basis van het orgaanstelsel waarin de tumor ontstaan is 14 . De afdeling pathologie azM is sinds 2003 afgestapt van een generalistische benadering. en overgegaan tot deelspecialisatie, waardoor thans alle takken van oncologische sport door koppels van supergespecialiseerde pathologen met juiste diagnosen ondersteund kunnen worden.

"Efficiënt" in de zorg houdt in: zonder verspilling van middelen, materialen, ideeêrn of energle. De inbreng van de patholoog is zeer efficiënt, aangezien de diagnose die de patholoog stelt op weefsel of slechts enkele cellen, tegen een relatief laang tarief tot stand komt, doorgaans eenmalig en definitief is, en hierdoor sommige andere en duurdere vormen wan diagnostiek overbodig kan maken. Dit besef zou bij clinici dienen te leiden tot het eerder inschakelen van de patholoog.

De "tijdigheid" van zorg, de problematiek van wachttijden, is een leder bekend. De doorlooptijd van een onderzoek door de patholoog (tussen 3 en 5 dagen) kan en mag echter nooit leiden tot wachttijd voor de patient. 
Ook "patiênt gecentreerdheid" is standaard voor de aanpak van de patholoog. Hoewel de patient zelf niet een directe behandelrelatie heeft met de patholoog, is kennis van individuele kenmerken als geslacht, leeftijd, klinische gegewens en medische voorgeschiedenis onontbeerlijk voor een goede klinisch pathologische diagnose.

"Gelijkwaardigheid", waarmee bedoeld wordt dat iedereen dezelfde behandeling verdient, ongeacht persoonlijke of geografische kenmerken, is in de Pathologie een open deur. Het kan niet zo zijn dat een gezwel in Groningen kwaadaardig is, en in Maastricht een goedaardig pukkeltje. Dankzij het relatief kleine aantal pathologen in Nedeland, een adequate richtlijnontwikkeling, een intensieve visitatie- en kwaliteitscontrole systematiek, gedegen bij- en nascholing, en goede afstemming van de opleidingen, mag dit geen wezenlijk probleem vormen.

Bij "veiligheld" wil ik tenslotte wat uitgebreider still staan. Dezelfde "Committee" in de VS heeft in 1999 een rapport uitgebracht, getiteld "To Err is Human: building a safer health system" 15 . Hierin wordt aangegeven dat in de Verenigce Staten medische fouten, met rond de 100.000 gevallen per jaar, meer sterfte veroorzaken dan bijwoorbeeld auto-ongevallen, borstkanker en AIDS. Weinigen onder $U$ zullen zich realiseren dat meer dan $70 \%$ van de medische handelingen bij een patiënt sterk beïmvloed wordt door uitspraken van de patholoog. Wij kunnen daarbij falen, door verkeerde invoer van patiënten gegevens, verwisseling of kwijtraken van hun materiaal, technische onvolkomenheden, beoordelingsfouten, nalatigheden, onjuiste rapportage, communicatleproblemen, etc. etc. Fouten in de praktijkvoering van de patholoog kunnen direct leiden tot onderbehandeling, overbehandeling, foutieve behandeling en in het ergste geval tot het overlijden. Getallen hierover in de literatuur variëren sterk, van I tot maar liefst $43 \%$, afhankelijk van het soort afdeling en de nauwkeurigheid van registratie ${ }^{16}$.

Hoewel men kan redetwisten of een bedrijfsmatige aanpak in de geneeskunde alles oplost, kan het voor Risicobeheersing In de Patièntenzorg geen kwaad am een voorbeeld te nemen aan de industrie of luchtvaart. De patholoog dient op de hoogte te zijn van de risicoss van zijn werkzaamheden, en te streven naar preventie van fouten. Hierbij is een goed kwaliteitssysteem, met uniformering van procedures, protocollering, gebruik van checklijsten en zoveel mogelijk interne controles (door b.v. dubbele beoordeling van preparaten) nodig, nalast een voortdurend besef van het belang en de potentiele gevolgen van iedere diagnose. 
Van de 12 oncologische zorglijnen in het azM, is die van kanker van het maagdarmkanaal qua wolume en van de grootste. Meer dan $20 \%$ van alle kwaadaardige aandoeningen in Nederland ontstaat in het maagdarmkanaal, en is daarmee verantwoordelijk woor $24 \%$ van de totale kankersterte ${ }^{17}$. Mijn inzet in de kinische pathologie speelt zich vooral op dit terrein af. Collega Ann Driessen en ik verzorgen de diagnostische en consultatieve functies binnen de gastro-intestinale pathologie, en werken hierbij nauw samen met de collegae gastrointestinale chirurgen, gastro-enterologen, internist-oncologen, radiotherapeuten, nucleair geneeskundigen en radiologen. Steeds meer tijd wordt hierbij geinvesteerd in multidisciplinaire besprekingen, warin alle patienten besproken worden en na gemeenschappelijk overleg beslissingen rond het te volgen medisch beleid genomen worden. Het azM fungeert als. regionalial centrum op het gebied van de behandeling van slokdarmkanker, kanker wan de galwegen en alvleesklier "de behandeling wan ver voortgeschreden kanker van de endeldarm en van uitzaaiingen van dikke darmikanker naar de lever. De meeste voorkomende tumor in het maagdarmkanaal betreft kanker van de dikke darm, verantwoordelijk voor $13.5 \%$ van alle kwaadaardige aandoeningen, en voor een sterfte van ruim 11\%. Deze ziekte heeft traditioneel mijn grootste klinische en wetenschappelijke belangstelling.

\section{Research In Preventie}

Darmkanker is een ziekte die ontstaat door accumulatie van genetische afwijkingen, weeffouten in het DNA. Deze genetische afwijkingen zijn in een klein percentage erfelijk, komen bij bepaalde families vaker voor, of ontstaan door de inwerking van omgevingsfactoren, samemhangend met de leefstill en voeding. Ook individuen met chronische ontstekingsprocessen van de darm hebben een verhoogde kans op het krijgen wan deze ziekte. Een kwaadaardig gezwel, aangeduid als adenocarcinoom, ontwikkelt zich gedurende vele jaren uit normaal slijmvlies. doorgaans wia een voorstadium van een poliep of adenoom.

In Nederland wordt jaarlijks bij een kleine 10.000 mensen darmkanker vastgesteld, nagenoeg gelijkelijk verdeeld over beide geslachten. Dit aantal zal in een wergrijzende bevolking naar schatting oplopen tot rond cle 13.500 jaarlijks in 2020 . Per jaar sterven rond de 4400 patienten, en 20 'n $56 \%$ van alle patienten is 5 Jaar na het stellen van de diagnose nog in leven 17. De kans dat een individu gedurende het leven damkanker krijgt ligt rond de $5 \%$. De primaire behandeling bestaat uit operatieve verwijdering van het aangedane deel van de darm met de naburige 
lymfklieren. Aan patienten die uitzaaingen hebben in lymfklieren of in andere organen zoals de lever, wordt aanvullende chemotherapie gegeven.

De overlevingskans is het grootst wanneer de ziekte in een vroeg stadium behandeld wordt, en neemt aanzienlijk af bij aanwezigheid van uitzaaiingen. De sterfte aan darmkanker is ondanks de inzet van velen slechts weinig afgenomen in de voorgaande decennia. Om deze verder te reduceren blijft veel onderzoek nodig. Globaal kunnen hierbij vier richtingen worden onderscheiden: 1) studies naar het ontstaan en beloop van darmkanker, 2) studies naar prognostische en predictieve factoren, die de overlevingskans respectievelijk de gevoeligheid voor verschillende vormen van behandeling beter kunnen voorspellen, 3) het ontwikkelen van nieuwe therapievormen, en 4) het streven naar primaire en secundaire preventie van kanker, door aantonen en wegnemen van risicofactoren, respectievelijk het wroegtijdig opsporen van kanker.

De afdeling. Pathologie azM heeft in zijn historie van darmkanker onderzoek aan al deze onderdelen bijgedragen, onder de bezielende leiding van Fré Bosman en Jan-Willem Arends, met wie ik vruchtbare jaren heb gedeeld. De hierbij opgebouwde kennis van de ontwikkeling van darmkanker wordt thans ingezet voor de vroege opsporing van darmkanker. Pilot studies in het buitenland hebben al uitgewezen dat darm kankersterfte met 15 tot $33 \%$ kan worden verminderd door screenen ${ }^{18}$. Deze zogenaamde secundaire preventie is zeer actueel en past uitstekend in het nationalle zorgbeleid en het beleid van het azM. "Carcinogenese en preventie" vormt een van de drie hoofdlijnen van onderzoek van het zich ontwikkelende Universitair Kankercentrum Maastricht.

Het preventie onderzoek richt zich op het vinden van DNA afwijkingen die specifiek zijn voor darmkanker, en die getest kunnen worden in bloed en ontlasting van individuen, met als doel om een eventueel aanwezig kwaadaardig gezwel in een zo vroeg mogelijk, nog te genezen stadium op te sporen. Hiertoe wordt nauw samengewerkt met de afdeling Castro-enterologie Maastricht, onder leiding van Reinhold Stockbrügger. Met steun van de Raad vam Bestuur azM, en toestemming van het Ministerie van WWS ${ }^{19}$ is inmiddels een aanvang gemaakt met een lokaal darmkanker screeningsproject onder oudere werknemers van regionale bedrijven, met een looptijd van 1o jaar. Verder bestaat er een belangrijke samenwerking op dit terrein met Gerrit Meijer, afdeling pathologie van de Wrije Universiteit te Amsterdam. De uitkomsten van dit onderzoek zijn bepalend woor het besluit van de Minister om te kunnen beginnen met landelijk bevolkingsonderzoek naar darmkanker in 2010. 
Samen met Plet van den Brandt en Matty Weijenberg van de afdeling Epidemiologie te Maastricht wordt al jaren in harmonieuze samenwerking gezocht naar relaties tussen DNA afwijkingen in tumoren en leetstijl factoren, zogenaamde Moleculair Epidemiologische studies.

Al dit werk is gebaseerd op de relatief recente ontdekking dat niet uitsluitend genetische veranderingen, in de zin van veranderingen in dle volgorde van DNA, verantwoordelijk zijn voor de ontwikkeling van kanker "doch ook epi-genetische veranderingen, in de zin van veranderingen in de regulering van DNA. Eenvoudig gezegd komt het erop neer dat genen die beschermen tegen het ontstaan van kanker uitgeschakeld worden door promoter methylering, een bepaalde chemische modificatie van het DNA. De techniek om deze modificaties aan te tonen is ontwikkeld in het laboratorium van Steve Baylin en Jim Herman, van de Johns Hopkins Universiteit in Baltimore ${ }^{20}$ en tijdens een postdoctorale stage door Manon van Engeland, mijn meest gewaardeerde onderzoekspartner, geleerd en vervolgens in Maastricht geintroduceerd. Onder haar bezielende dagelijkse leiding zijn thans een zestal promovendi actief. Het onderzoek wordt financieel ondersteund door twee projecten bij NKB/Koningin Wilhelminafonds, een projekt bij ZON/MW, een bij de Transnationale Universiteit Limburg, en een grote overheids subsidie van Senter/Novem, samen met Gerrit Meijer en Herman Spolders, van het in Epigenetica gespecialiseerde bedrijf Oncomethylome Sciences.

\section{Rolmodel Is Primair}

We bevinden ons in een tijdperk van sterke verandering van de zorg, met een vergrijzende bevolking, betere behandelingsmogelijkheden, meer complexe en chronische ziekten. Hierdoor zullen de organisatie van zorg, en de eisen aan de moderne arts veranderen ${ }^{27}$.

Er zijn meer artsen nodig, die hun professie anders dienen in te vullen. De opleiding dient korter te worden en beter. Inhoudelijk wordt de opleiding anders, maar ook qua structuur.

Er is een continuüm van opleiding van basisarts tot en met medische specialist, die in feite al begint met de tweede fase van het WWO. De kwaliteit van het eindproduct wordt meer en meer afhamkelijk van de voorgaande onderdelen, waarvan de eindtermen dan ook op elkaar afgestemd dienen te zijn. De onderwijskundige principes zijn voor alle onderdelen vergelijkbalar. Er dient niet alleen aandacht te bestaan voor opbouw van kennis en vaardigheden, maar ook woor ontwikkeling van de juiste attitude, professioneel gedrag, voor wetenschappelijke vorming planning en organisatie, communicatie, en samenwerking. 
Opleidingen zijn steeds meer modulair van structuur wat betreft cursorisch onderwijs en toetsing. De student dient een portfolio bij te houden, en wordt anderworpen aan weelzijdige toetsingswormen. Er dient tijdige en adequate feed-back plaats te vinden, in een goed en veilig opleidingsklimaat. Docenten dienen hierbij toegankelijk te zijn, en te zorgen voor een open communicatie, en voldoende contactmogelijkheden met de student.

Ook de structuur van het onderwijs is onder invloed wan Europese regelgeving veranderd. Zo wordt de Bachelor-Master ook ingevoerd in de geneeskunde, en kennen we in Maastricht de ontwikkeling van een graduate entry program woor zij-instromers en een honoursprogram voor de extra gemotiveerde student. Het laatste opleidingsjaar zal dankij gerichte stages kunnen dienen als schakeljaar, waardoor de specialisten opleiding korter zou kunnen worden.

In de pathologie leidt de aard van het werk aan het microscoop van oudsher tot het meester-gezel principe als tot dusver onovertroffen opleidingsvorm, die temidden van zoveel veranderingen zeker stand zal houden. Hierbij is het geven van het juiste voorbeeld in de klinische praktijk en het wetenschappelijk onderzoek het belangrijkste leermoment: het Rolmodel is Primair. Pathologie als vakgebied van basale ziekteleer heeft het echter moeilijk in een multidisciplinair curriculum, en heeft behoefte aan een herkenbare positionering, een eigen gezicht, met voldoende mogelijkheden voor onderwijsinbreng binnen dit curriculum.

Voor de patholoog als docent geldt dat deze een degelijke basis in kliniek en wetenschap dient te hebben, een goedle motivatie, en bekend te zijn met leren leren en continu leren. Dit alles staat of valt echter met een helder toekomstperspectief en goede mogelijkheden voor promotie in een onderwijs carrière.

\section{Synthese: Redenen om te investeren in de Pathologie}

Tot slot kom ik tot de synthese. Dit begrip verbindt de afzonderlijke onderdelen tot een nieuw en coherent geheel. In de dialectische fllosofie van Hegel benadert de synthese de walarheid beter dan de afzonderlijke elementen van these en antithese. Ik schetste $U$ de tegenstelling van een vak dat op sterven na dood zou zijn in de these, en een wak dat thans een wedergeboorte zou doormaken in de antithese, in een samenspel van sterkten en zwakten, kansen en bedreigingen. Om deze dialectische kloof te kunnen overbruggen, stel ik $U$ als synthese voor: de noodzaak van het overleven van de academische Pathologie, onmisbaar binnen de geneeskunde, als grondslag voor kennis van ziekten, als centrale diag- 
nostische discipline en als brug tussen basale en klinische research.

Hiertoe dient strategisch gedacht te worden, vanuit de eigen organisatie in relatie tot de omgewing, met aandacht voor structuur, verantwoordelijkheden, incentives, leiderschap en de mens op de werkvtoer als. Maat der Dingen. Om te kunnen overleven zijn er voor vele betrokkenen dan ook goede Redenen om te Investeren in de Pathologie. "Inside out" noem ik enkele:

Leiding wan de afdeling. Goed leiderschap uit zich in medewerkers die graag bij de afdeling willen horen. Aandacht hebben voor zowel de successen als de problemen. Het schetsen van een helder toekomstperspectlef voor medewerkers van hoog tot laag.

Staf Pothologie. Plezler hebben in elk van de academische taken, deze alle drie even belangrijk vinden "mar ook beseffen dat niet iedereen even bekwaam kan zijn op elk onderdeel. Ambitieus, maar ook realistisch zijn ten aanzien van de eigen carrière mogelijkheden. Investeren in teamwork, en imzien dat het geheel sterker behoort te zijn dan de som der delen. Een rolmodel zijn voor arts-assistenten, analytisch en administratief personeel.

ANOS. Van het prille begin werken aan zelfstandigheid en zelfvertrouwen bij het oplossen van de dagelijkse diagnostische problemen. Een hecht team willen vormen, onderling en met de supervisoren, en samen uitstralen dat het vak waarvoor je gekozen hebt het mooiste is.

OBP. De kurk waarop de afdeling drijft. De vanzelfsprekendheid van jullie aanwezigheid en goede inzet zou wat vaker vervangen dienen te worden door dankbaarheid.

Raad van Bestuur azM en Bestuur van de Faculteit der Geneeskunde.

Dienen zich rekenschap te gevern van de centrale rol van de pathologie bij het vervullen van taken in zorg, wetenschappelijk onderzoek en opleiding, en dit niet als vanzelfsprekend te aanvaarden, maar juist pro-actief te zorgen voor het consolideren en verbeteren van de concurrentie positie van de eigen pathologle afdeling. In algemene zin dienen bestuurders zich te realiseren, dat de grenzen van de output van een academische afdeling, tegen de conflicterende achtergrond van een belangrijk toenemende zorgvraag en productie enerzijds, en een belangrijk afnemend financieel kader om deze productie te kunnen leveren anderzijds, dichter bij zijn dan men denkt. Alleen ruimhartige waardering in materiële en immateriële zin van wetenschappelijk en ondersteunend personeel kan een dreigende decompensatie keren. Ten behoeve van de wetenschap dienen Bestuurders te jveren woor het 
aanvaardbaar maken bij overheid en publiek van een "geen bezwaar" regeling bij het nader gebruik van restmateriaal wan patienten woor wetenschappelijk onderzoek.

Klinische vakgenoten. Wij prijzen ons gelukkig dat wil jullie vragen naar eer en geweten mogen beantwoorden. In ruil hiervoor verlangen wij slechts respect voor onze rol als artsen met een bijzondere diag. nostische vaardigheid, en de gelegenheid om serieus mee te doen aan klinische besluitvorming rond de patiënt.

Patiënten. Voor jullie proberen wij de 6 genoemde criteria van goede zorg te vervullen. In de toekomst treden wij pathologen hopelijk wat meer uit de schaduw. Persoonlijke contacten tussen klinisch patholoog en patienten, zoals in de Verenigde Staten reeds voorkomen, zullen ook in onze contreien wellicht steeds vaker plaats kunnen vinden.

Collegae pathologen in den lande. Draag $U$ vak met enthousiasme uit. Slechts actieve profilering leidt tot een verbeterd imago.

Collegae pathologen in de regio. Zie ons niet als hautaine concurrenten, en zoek vaker de samenwerking. Ik garandeer $U$ dat de academische pathologie dit zal verwelkomen.

Onderwijsorganisatie. Inzien dat kennis van ziekten binnen de geneeskunde opleiding nergens beter overgedragen kan worden dan binnen een afdeling pathologie, en dit besef vertalen in meer mogelijkheden voor de pathologie om haar boodschap binnen het curriculum uit te kunuer dragen.

Studenten. Ga ervoor. Wacht niet tot jullie rooster aangeeft dat je naar de pathologie kunt. Kom zelf naar ons toe, en besef: pathologie is belangrijk, pathologie is best leuk, en pathologie is niet zo moeilijk.

Dames en heren, in de chemie is synthese een proces wararbij uit een onderlinge reactie van meerdere componenten een gewenst product tot stand komt. lk heb $U$ willen tonen dat noodzakelijke Overleving van de Academische Pathologie evenzeer een product is, dat uitsluitend door de goede chemie tussen vele componenten tot stand kan komen. 


\section{Dankwoord}

Dankzij de inzet, medewerking, steun en bielangstelling van zeer velen binnen en buiten mijn werk sta ik hier. De meeste blijen anoniem, maar daarom niet minder belangrijk voor mij.

Enkelen noem ik hier met name:

College van Bestuur van de Universiteit Maastricht, Bestuur van de Faculteit der Geneeskunde, Raad van Bestuur van het Academisch Ziekenhuis Maastricht, Bestuur van de Stichting St. Annadal en Leden van de Commissie van Toezicht: $U$ allen dank ik voor het uitgesproken vertrouwen in mij.

Hooggeleerde Bosman, beste Fre, als opleider, promotor en vriend sta jij aan de wieg van dit alles. Jij zult voor mij altijd "the man in the doorway" blijven, die op de achtergrond meekijkt. Dank voor het goede voorbeeld dat jil geweest bent.

Hooggeleerde Arends, beste Jan-Willem, je was mijn baas en blijft mijn goede vriend. Wij hebben het laatste deel van het voorgaande Millennium buitengewoon interessante jaren gedeeld. Helaas heeft dit niet mogen voortduren. De herinneringen aan deze tijd koester ik. Ook jou dank ik hiervoor.

Hooggeleerde Daemen, beste Mat, vriend en "brother in arms". Iij hebt de aanzet gegeven tot dit hele gebeuren. Soms weet ik zeker dat ik je hier dankbaar voor ben, soms vraag ik het me serieus af. Samen met jou hoop ik nog heel wat jaren het Pathologie bedriff te kunnen runnen.

Hooggeleerde Stockbrügger, beste Reinhold, al jaren vinden wij elkaar op onze gemeenschappelijke hobbies vam de Castroenterologie en La Dolce Vita. Onze samenwerking op klinisch en wetenschappelijk gebied is voor mij altijd van grote waarde geweest.

Zeergeleerde Van Engeland, beste Marion, ik hoop dat wij de tandem waa rop wij rijden nog heel lang op de weg kunnen houden, en dat wij onze wetenschappelijke telgen samen goed mogen opwoeden.

Staf en AlOS Pathologie: er zijn ups en er zijn downs, maar uiteindelijk resteert het gevoel van geluk dat ik in jullie midden mag werken.

Ondersteunend personeel: zonder jullie bestond er geen Pathologie, daarvoor de grootste dank.

Mijn Ouders, jullie hebben mij tijdens een gelukkige jeugd gevormd. en hiervoor ben ik zeer dankbaar. Mama, ontzettend fijn dat $U$ hier bij kunt zijn. Papa mag dit helalas niet meer bijwonen, maar ik weet dat hij net zo trots zou zijn geweest als op mijn promotiedag. 
Willem en Sica, lieve broer en zuster, ik hoop dat wij altijd zo eén zullen blijven.

Dames en heren, er zijn ook nog andere dingen in het leven dan werken, en er zijn talrijke Redenen om te Investeren in mijn Privé-leven.

Just, Eline en Isabelle، jullie zijn mijn grootste geluk.

Tot slot Sophie. Ik had gehoopt dat ik na mijn promotie in 1993 wat meer tijd voor jou en de kinderen zou kunnen maken. We weten hoe dat gelopen is. Ik ga die hoop hier niet opnieuw uitspreken. Wel hoop ik dat ik mij ondanks alles nog "Sophie"s Choice" mag blijven noemen, en dat ik, hoewel ik met deze dialectische oratie slechts de rol van "tijdelijk filosoof" heb aangenomen, nog steeds een rol mag blijven spelen in "Sophie's World". Ik kan je in ieder geval beloven dat ik een permanente aanhanger van de "filo-sophie" zal blijven.

lk ben je dankbaar voor alles wat je mij geeft.

Ik heb gezegd. 


\section{Bibliografie}

1. Committee on Quality of Health Care in America, Instutute of Medicine Crossing the Quality Chasm: A New Heatth System for the 215t Century. Washington DC. National Academies Press; 2001.

2. Berman U. Pathology Abbreviated A Long Review of Short Terms. Arch Pathol Lab Med 2004; $28: 347752$

3. Hunter M. Alder Hey report condemns doctors, management and coroner. BM 2001:322:255.

4. Claim na geknoet met organen. NRC Handelsblad, 4-02-2006.

5. Geinteresseerd in Liken. NRC Handelsblad, 18-08-2004.

6. Verbraak C. Vertalers van de Dood. Vrij Nederland, week 3, 2006.

7. Lambert TW. Coldacre M. Turner $G$, Domizio P. DuBoulay $C$. Career choices for pathology: national surveys for graduates of 1974 -2002 from UK medical schools. I Pathol 2006; 208:446-52.

B. Lyons $A S_{\text {i }}$ Petrucell II R. Medicine. An Hllustrated History Abradale Press Harry N Abirams, Inc, Publishers, Niew York 1987

9. King LS, Meehan MC. A History of the Autopsy. A Review. Am I Pathol, 1973 Nov; $73(2): 514-44$

10. Scaranl P, Rudolf virchow (1821-1902). Virchows Arch. 2003 Feb;442(2):95; 8 .

7. Vermeulen $A$. De HE-kleuring, een vertrouweling op leeftid http:/ www path. unimaas.ni/news/Junl2005, httm

12. Ransohoff DF. Rules of evidence for cancer molecular-marker discovery and validation. Nat Rev Cancer 2004 Apr;4(4):309-14.

13. Rosal 1. The continuing role of morphology in the molecular age. Mod Patholi. 2001 Mar; $14(3): 258-60$.

14. Van den Brandt $P$, Von Meyenfeldt. M. Wan Dun $K$, Gorissen P. Stuurgraep Kankercentrum. Visiedocument RVE Oncologie. 4 mei 2006.

15. Kohn KT, Cormgan IM, Donaldson MS. To Err is Human: Bulding a Safer Health System. Washingtor DC: National Academles Press; 1999.

16. Condel IL, Jukic DM, Sharbaugh DT, Raab S5. Histology Errors. Use of Real-Time Root Cause Analysis to Improve Practice. Pathology Case Reviews 2005; 10:8287 .

17. ht.p:/wwwkwfkankerbestrijding nl/content/pages/Totalowerzicht_kanker in Nederland htm

18. Ransohoff DF. Colorectal cancer screenimg in 2005: Status and Challenges. Gastroenterology $2005,128: 1685-95$.

19. Brief Munisterte van VWS, mel 2006 "Nadere standpuntbepaling bevolkingsonderzok darmkanker".

20. Herman $J C_{3}$ Baylin $5 B$ Gene silencing in cancer in association with piromoter hypermethylation. N Engl I Med. 2003 Now 20,349(21):2042-54.

21. De arts wan straks. Een nleuw medisch opleidingscontinuüm. Gemeenschappelijke uitgave van KNMG, DMWW-VSNU,VAZ, NVZ, LCVV, Utrecht oktober $2002158 N 90-71994-28-7$

22. Ancyclopaed Britannica Online. Academic Edition.

27. http:/nilwikipedia.org

24. httep://winkleiprins mrc.n// 
